\title{
The Pronunciation of Noun Suffix “子” in Pinghua Dialect Used by Miao and Yao Autonomous in Southwest Hunan of China
}

\author{
Ping Wu, Ping Hu \\ College of Politics and Law, Central South University of Forestry and Technology, Changsha, China \\ Email: wuping79@126.com
}

Received 30 April 2015; accepted 10 June 2015; published 16 June 2015

Copyright (C) 2015 by authors and Scientific Research Publishing Inc.

This work is licensed under the Creative Commons Attribution International License (CC BY). http://creativecommons.org/licenses/by/4.0/

cC) (i) Open Access

\begin{abstract}
In Pinghua dialect used by Miao and Yao autonomous in southwest Hunan of China, Beijing dialect's noun suffix “子” has different literary and colloquial forms such as the pronunciation [•ts1] and many other unique colloquial pronunciations that each pronounced as a syllable. By synthetically analyzing many pronunciation forms of noun suffix “子” in Pinghua dialect used by Miao and Yao autonomous, this paper gives an investigation on the phonetic change and historical levels.
\end{abstract}

\section{Keywords}

Southwest Hunan, Pinghua Dialect Used by Miao and Yao Autonomous, Noun Suffix “子”, Pronunciation

\section{Introduction}

"Pinghua dialect used by Miao and Yao autonomous in Southwest Hunan" is refers to the dialect used by the part of Miao (Yao) people in the Chengbu Miao Autonomous County, Suining County and Xinning County which are located at the border of southwest Hunan and Guangxi province. This dialect is called by local people as "Pinghua", "Renhua”, "Miaohua", "Donghua”, etc. (Hu, 2009). This dialect is mainly distributed in Guanxia Miao and Changpuzi Miao Autonomous Town in Suining, in Lanrong, Baimaoping, Tingping, Wutuan, Pengdong and Jiangtousi Town in southeast Chengbu, in Dankou and Yangshi Town in northwest Chengbu, as well as in Malin and Huangjin Town in Xinning.

In Mandarin Chinese the word-building ability of “子 [•ts]]" is very strong. In Pinghua dialect used by Miao and Yao autonomous in southwest Hunan the suffix "子” also exists, but it is more common with different pronunciation forms. By synthetically analyzing many pronunciation forms of noun suffix “子” in Pinghua dialect

How to cite this paper: Wu, P., \& Hu, P. (2015). The Pronunciation of Noun Suffix “子” in Pinghua Dialect Used by Miao and Yao Autonomous in Southwest Hunan of China. Open Journal of Modern Linguistics, 5, 250-254. 
used by Miao and Yao autonomous, this paper gives an investigation on the phonetic change and historical levels.

\section{Noun Suffix “子” in Pinghua Dialect Used by Miao and Yao Autonomous in Southwest Hunan and Pronunciation Forms}

In Pinghua dialect used by Miao and Yao autonomous in southwest Hunan, the noun suffix “子” has different pronunciation forms of literary and colloquial pronunciations, such as [•เ⿱亠乂$]$ and other unique forms, which are all used as self-syllable.

According to the investigation and the existing data, in Pinghua dialect used by Miao and Yao autonomous in southwest Hunan, the nouns suffix “子 [•• ] ]" are generally used for loanwords or after words, whose pronunciation has obvious characteristic of literary pronunciation, Whose amount is not much, and whose word-building ability is weak. Taking the Malin dialect in Xinning county as an example:

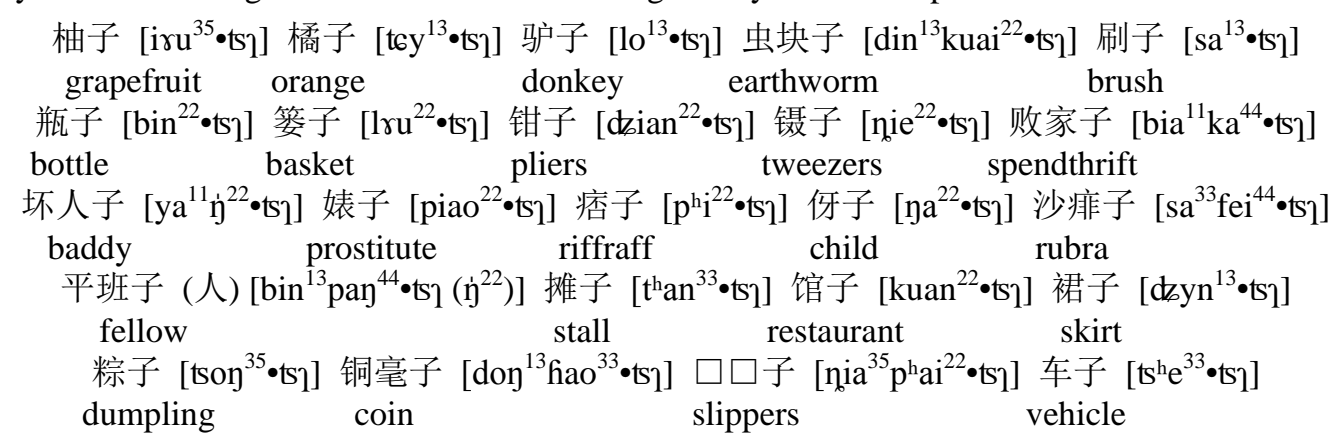

In specific, some words above were borrowed with external things together, such as grapefruit, orange, pliers, tweezers, skirt, slippers, dumplings, etc. There were not these things in local place, so borrow of these things caused the whole borrow of words sounds and meanings. At the same time some words above had replaced the original nouns, such as “满伢子 $\left[\mathrm{mai}^{22} \mathrm{ya}^{22} \bullet \mathrm{s}\right]$ ]”, “侄伢子 $\left[\mathrm{tci}^{13} \mathrm{ya}^{22} \bullet\right.$ ts $]$ ”. The meaning of “伢子” in Xinning dialect is child, while in Malin dialect the corresponding word is “惫崽 [tsai ${ }^{22} \bullet$ tsai]”. The specific substitution of other words is to be further investigated.

On the contrary those unique forms of the noun suffix “子” belong to the local, which word-building ability is strong, and are generally used for local nouns calling the local things, being specific, small in semantics and derogatory and common in pragmatics. Taking the Ma Lin dialect in Xinning county as an example too:

(Specific things) wheat 麦子 $\left[\mathrm{ma}^{11} \cdot\right.$ te], rhododendron 红花子 $\left[\mathrm{hog}^{13} \mathrm{fa}^{33} \cdot \mathrm{te}\right]$, horse 马公子 $\left[\mathrm{ma}^{22} \mathrm{ko \eta}^{35} \cdot \mathrm{te}\right]$, face 面子 $\left[\mathrm{mie}^{11} \mathrm{lo}^{22} \cdot \mathrm{te}\right]$, fine hair 寒毛子 $\left[\mathrm{ho}^{22} \mathrm{mo}^{13} \cdot \mathrm{te}\right]$; (small things) star 星子 $\left[\mathrm{sai}^{35} \cdot \mathrm{te}\right]$, sand 沙子 $\left[\mathrm{cia}^{35} \cdot \mathrm{te}\right]$, town 镇子 $\left[\right.$ nia $\left.^{35} \mathrm{tcia}^{35} \cdot \mathrm{te}\right]$, mosquito 蚊子 $\left[\mathrm{mon}^{35} \cdot \mathrm{te}\right]$, bow shoe ${ }^{1}$ 包子鞋 $\left[\mathrm{ha}^{33} \mathrm{pru}^{44} \bullet \mathrm{te} \mathrm{ia}^{13}\right.$ ]; (derogatory things) lunatic 摆子 [pai ${ }^{22} \bullet$ te], lunatic 癫子 $\left[\mathrm{tie}^{35} \bullet\right.$ te], cripple $\square$ 子 (瘏子) [pai ${ }^{33} \cdot$ te], human trader 人贩子 $\left[\dot{n}^{13} \mathrm{fai}^{44}\right.$ te], deaf-mute 狵子 $\left[\mathrm{lay}^{13}{ }^{\circ} \mathrm{te}\right]$; (common things) chair 椅子 $\left[\mathrm{i}^{22} \bullet\right.$ te], box 箱子 $\left[\mathrm{cio}^{35} \bullet\right.$ te], cup 酒瓯子 $\left[\mathrm{tsei}^{33} \mathrm{ao}^{44} \bullet\right.$ te], thimble 手 $\square$ 子 $\left[\mathrm{cy}^{22} \mathrm{tie}^{22} \bullet\right.$ te], roller $\square$ 子 [lei ${ }^{13}$ •te], etc..

In several other points of Pinghua dialect used by Miao and Yao autonomous, there are different pronunciation forms of noun suffix “子”, as shown in Table 1.

Obviously, the colloquial pronunciation of noun suffix “子” in Pinghua dialect used by Miao and Yao autonomous in Southwest Hunan is different from that in Mandarin. At the same time, although the colloquial pronunciation forms of Pinghua dialect area above are various, but the main vowels of which are all read as [ə] or [e], and the initials are all read as [t] or [l], the similar pronunciation indicates the direct or indirect speech contact.

\section{Analysis of the Phonetic Change and Historical Levels Noun Suffix “子” in Pinghua Dialect Used by Miao and Yao Autonomous in Southwest Hunan}

The variety of pronunciation forms of noun suffix “子” in Pinghua dialect used by Miao and Yao autonomous in

${ }^{1}$ the shoes with upturned end worn by women with bound feet in former times. 
Table 1. Comparison table of colloquial pronunciation of noun suffix “子” in Pinghua dialect used by Miao and Yao autonomous in Southwest Hunan.

\begin{tabular}{|c|c|c|c|c|c|}
\hline Vocable & $\begin{array}{c}\text { Malin town } \\
\text { Xinning county }\end{array}$ & $\begin{array}{l}\text { Lanrong town } \\
\text { Chengbu county }\end{array}$ & $\begin{array}{l}\text { Yangshi town } \\
\text { Chengbu county }\end{array}$ & $\begin{array}{l}\text { Guanxia town } \\
\text { Suining county }\end{array}$ & $\begin{array}{c}\text { Mati town } \\
\text { Longsheng county }^{2}\end{array}$ \\
\hline $\begin{array}{l}\text { 星星 } \\
\text { star }\end{array}$ & sai $^{35} \cdot$ te & $\mathrm{se}^{55} \cdot$ tie & $\sin ^{24} \cdot$ to & $\mathrm{se}^{33} \cdot \mathrm{le}$ & $\mathrm{ee}^{55} \mathrm{le}^{33}$ \\
\hline $\begin{array}{l}\text { 沙子 } \\
\text { sand }\end{array}$ & $6 \operatorname{cia}^{35} \cdot$ te & $6 i a^{55} \cdot$ tie & $\mathrm{sa}^{24} \cdot \mathrm{t} ə$ & $\mathrm{so}^{33} \cdot \mathrm{le}$ & $1 a^{55} \mathrm{le}^{33}$ \\
\hline $\begin{array}{l}\text { 麦子 } \\
\text { wheat }\end{array}$ & $\mathrm{ma}^{11} \cdot$ te & $\mathrm{ma}^{11} \cdot$ tie & $\operatorname{cia}^{44} \mathrm{ma}^{21} \cdot$ tə & $\mathrm{mo}^{213} \cdot \mathrm{le}$ & $\mathrm{ma}^{21} \mathrm{le}^{33}$ \\
\hline $\begin{array}{l}\text { 蝌蚪 } \\
\text { todpole }\end{array}$ & io $^{35} \mathrm{ma}^{33} \cdot$ te & io ${ }^{55} \mathrm{ma}^{24} \cdot$ tie & $\mathrm{io}^{24} \mathrm{ma}^{21} \cdot \mathrm{to}$ & $\mathrm{i}^{4} \mathrm{u}^{44} \mathrm{mo}^{21}$ (秧嘛)・le & $\mathrm{ma}^{22}$ (麻) $\mathrm{le}^{33}$ \\
\hline $\begin{array}{l}\text { 椅子 } \\
\text { chair }\end{array}$ & $\mathrm{i}^{22} \cdot$ te & $\mathrm{i}^{33} \cdot$ tie & $i^{45} \cdot$ to & $i^{53} \cdot l e$ & $\mathrm{i}^{33} \mathrm{le}^{33}$ \\
\hline $\begin{array}{l}\text { 镜子 } \\
\text { mirror }\end{array}$ & $\tan ^{33} \cdot$ te & tciu ${ }^{44}$ (照)•tie & $\operatorname{tain}^{33} \cdot$ ta & $\operatorname{tcie}^{33} \cdot$ le & $\mathrm{mie}^{42} \operatorname{tciu}^{44}$ (面照) $\mathrm{le}^{33}$ \\
\hline $\begin{array}{l}\text { 辨子 } \\
\text { braid }\end{array}$ & pie $^{35} \cdot$ te & pie $^{44}$ otie & $\operatorname{pin}^{24} \cdot$ tə & $\mathrm{pie}^{33} \cdot \mathrm{le}$ & $\operatorname{pin}^{55} \mathrm{le}^{33}$ \\
\hline $\begin{array}{c}\text { 父子俩 } \\
\text { father and son }\end{array}$ & $\operatorname{lio}^{22} \mathrm{ia}^{22} \cdot$ te & io $^{33} \mathrm{ia}^{24} \cdot$ tie & $\operatorname{lio}^{33} \mathrm{ia}^{44} \cdot$ tə & $\mathrm{io}^{22} \operatorname{tsai}^{53} \mathrm{kan}^{44}$ (爷崽间) & $\mathrm{io}^{33} \mathrm{ia}^{42}$ (俩爷) $\mathrm{le}^{33}$ \\
\hline
\end{tabular}

Southwest Hunan cited above is closely related to its affiliated status. As an unfree morpheme noun suffix “子” is always attached to other morphemes, it has strong word-building ability but is lack of real significance, so it often have a soft tone-variation trend or have read to a soft tone, will naturally promote weak pronunciation. The track of phonetic evolution of noun suffix “子” can be inferred from two aspects of initials and finals.

\subsection{Vowel Centralization}

On the reconstruction of the medieval phonetic of “子” Wang Li's result was *tš̀ and Shao Rongfen's result was *tsie, both were Diphthong vowel. The noun suffix “子” in Lanrong town read [•tie], meanwhile the pronunciation of other two Chinese characters in Lanrong dialect can be the circumstantial evidence:

$$
\begin{array}{cc}
\text { 耳 (耳朵) }\left[\mathrm{nie}^{33}\right] & \text { 里 (colloquial pronunciation: 街里) }\left[\mathrm{lie}^{33}\right] \\
\text { ear } & \text { on the street }
\end{array}
$$

Supposing the pronunciation in Lanrong was the earlier level, we can infer that the early third-class rhymes had head vowel [-i-], and lost the head vowel in the weakening trend, that is:

The centralization centralization chain: ie $>\mathrm{e}>\mathrm{\rho}$

The original diphthong threw away head vowel [-i-] becoming to [e], and further to central vowel [ə]. The latter two pronunciation forms appear in the Malin and Yangshi dialect successively. In "The study of Jin dialect grammar" Qiao Quansheng (2000) has pointed out the pronunciation of the initial consonant of noun suffix “子” in Shanxi JinYu is various, but the vowel mainly read [•ə]. Visibly, the two situations are similar.

\subsection{Consonant Weakening}

The medieval phonetic of “子” was affricates [ts], in the weakening trend it firstly lost the fricative feature becoming to plosive [t], and further to Liquid [l].

The weakening chain: $t \mathrm{~s}>\mathrm{t}>\mathrm{l}$

Wang Hongjun (1999) has pointed out that in Shanxi dialect along with the vowel centralization the consonant weakening chain of noun suffix "子” is "affricates > plosive/fricative > liquid". The two situations are similar.

There is the same phenomenon of vowel centralization and consonant weakening in the Southern Hunan Tuhua and Pinghua which are not far from southwest Hunan. According to Luo (2006: p. 140), these unique forms are colloquial pronunciation, pronunciation [\$s] is literary pronunciation, which arose because of the effect of Mandarin in double dialect area, as shown in the following Table 2.

\footnotetext{
${ }^{2}$ The survey point is Niutou village in Mati town of Longsheng county, Guangxi province. Mati town is adjacent to the territory of Chengbu county, Hunan province, the dialect in Mati town belongs to the Miao and Yao dialect.
} 
Table 2. Pronunciations of noun suffix “子” in southern Hunan Tuhua.

\begin{tabular}{|c|c|c|c|}
\hline Dialects & Colloquial pronunciations & \multicolumn{2}{|c|}{ Examples } \\
\hline $\begin{array}{l}\text { Xinyu town in Lanshan county } \\
\text { (Luo, 2006) }\end{array}$ & •tse & $\begin{array}{l}\text { 构子 }\left[\mathrm{kei}^{45} \cdot \text { tse }\right] \\
\text { ice pellet }\end{array}$ & $\begin{array}{l}\text { 钉子 }\left[\text { tian }^{33} \cdot \text { tse }\right] \\
\text { nail }\end{array}$ \\
\hline \multirow{2}{*}{$\begin{array}{l}\text { Chengguan town in Linwu county } \\
\text { (Luo, 2006) }\end{array}$} & •tso & $\begin{array}{l}\text { 毫子 }\left[\mathrm{xau}^{13} \cdot \text { tsə }\right] \\
\operatorname{coin}\end{array}$ & $\begin{array}{c}\text { 蚌子 }\left[\text { ts }^{\mathrm{h}} \text { uen }{ }^{55} \cdot \text { tso }\right] \\
\text { fool }\end{array}$ \\
\hline & •ta & $\begin{array}{l}\text { 麦子 }\left[\mathrm{ma}^{33} \cdot \mathrm{t} \text { ] }\right. \\
\text { wheat }\end{array}$ & $\begin{array}{l}\text { 鸟子 }\left[\operatorname{tiou}^{55} \cdot \text { te }\right] \\
\text { bird }\end{array}$ \\
\hline $\begin{array}{l}\text { Chengguan town in Jiangyong county } \\
\text { (Luo, 2006) }\end{array}$ & $\mathrm{tie}^{35}$ & $\begin{array}{c}\text { 窗子 }\left[\operatorname{san}^{44} \mathrm{tie}^{35}\right] \\
\text { window }\end{array}$ & $\begin{array}{l}\text { 爷子 }\left[\mathrm{ya}^{42} \mathrm{tie}^{35}\right] \\
\text { father }\end{array}$ \\
\hline \multirow{2}{*}{$\begin{array}{l}\text { Pinghua dialect in Ningyuan county } \\
\text { (Zhang, 1999) }\end{array}$} & •ta & $\begin{array}{l}\text { 竹子 }\left[\mathrm{tsou}^{21} \cdot \mathrm{t} ə\right] \\
\text { bamboo }\end{array}$ & $\begin{array}{c}\text { 昨工子 }\left[\mathrm{ts}^{\mathrm{h}} \mathrm{o}^{21} \mathrm{kan}^{415} \bullet \text { tə] }\right. \\
\text { yesterday }\end{array}$ \\
\hline & •lə & $\begin{array}{l}\text { 格子 }\left[\mathrm{k} \partial^{213} \bullet \mathrm{l} ə\right] \\
\text { window }\end{array}$ & $\begin{array}{l}\text { 扁子 }\left[\mathrm{pan}^{33} \cdot \mathrm{l} ə\right] \\
\text { shoulder pole }\end{array}$ \\
\hline $\begin{array}{l}\text { Xianzijiao town in Dao county } \\
\text { (Wang, 2007) }\end{array}$ & $\cdot \mid \varepsilon$ & $\begin{array}{l}\text { 沙子 }\left[\mathrm{su}^{44} \cdot 1 \varepsilon\right] \\
\text { sand }\end{array}$ & $\begin{array}{l}\text { 树子 }\left[\operatorname{cyo}^{41} \cdot 1 \varepsilon\right] \\
\text { tree }\end{array}$ \\
\hline \multirow{2}{*}{$\begin{array}{l}\text { Wuba town in Dao county } \\
\text { (Luo, 2006) }\end{array}$} & $1 \gamma^{44} / \cdot 1 \gamma$ & $\begin{array}{c}\text { 枱子 }\left[\mathrm{tic}^{45} \mathrm{Ir}^{44}\right] \\
\text { desk }\end{array}$ & $\begin{array}{l}\text { 星星 }\left[\mathrm{su}^{24} \cdot \mathrm{l} \gamma\right] \\
\mathrm{star}\end{array}$ \\
\hline & $\operatorname{tr}^{44}$ & $\begin{array}{l}\text { 辣子 }\left[\mathrm{li}^{33} \mathrm{tr}^{44}\right] \\
\text { cayenne }\end{array}$ & 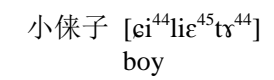 \\
\hline
\end{tabular}

There are similar phenomenon in other dialects. In Hebei dialect (Local Chronicles Compilation Committee

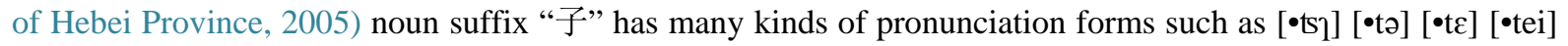
[zə], in Xingtai dialect (Dai, 2010) there are regional phonetic variants such as [•tə] [•ə]. In Shijiazhuang urban dialect (Zhao, 2009) and Anyang dialect (Cui, 2013) which are in the transition area of Jin dialect and Mandarin the pronunciation of noun suffix “子” reads [•tə]. In Jintan dialect (Wu, 2010) in Jiangsu province, which belongs to Wu dialect and contacts with Jianghuai Madarian, the noun suffix “子” reads [•tə?] outside the east gate, and [•tsə?] in urban areas and outside the west gate, such as: “羊子 (goat), 梨子 (pear), 房子 (house), 妹子 (younger sister), 老子 (father)”. In Shangqiu dialect (Zhang, 2008) in Henan province,which belongs to Zhongyuan Manderian, the noun suffix “子” after open syllable reads [•tei], such as: “桌子 (chair), 病子 (cripple), 孩子 (child), 柿子 (persimmon), 包子 (steamed stuffed bun), 猴子 (monkey)”, Zhang (2008) pointed out this pronunciation came from initial consonant stopping, vowel centralization, rising and cracking, the evolvement contrail may be “ $\$ 7>$ s $>t a>t e>t e i$ ". Visibly, all of the different pronunciation of noun suffix “子” are the results of phonetic evolution of initial consonant and vowel, initial consonant (such as [t] [l] etc.) are the weakening forms of [ts], vowel (such as [e] [ə] etc.) are the weakening or centralization forms of vowel [1].

Combined with the existing corpus and the phonological status of “子” in the medieval Chinese, writer considers that pronunciation of the noun suffix “子” maybe have the following evolution trend:

Gradation: $1^{\text {st }} 2^{\text {nd }} 3^{\text {rd }} 4^{\text {th }} 5^{\text {th }} 6^{\text {th }}$

Pronunciation: *tsie $>$ tie $>$ te $>$ tə/le $>$ (lə) $>$ (ə)

Sound system: medieval Lanrong Malin Yangshi/(Ningyuan town) phonetic town town Niutou, Guanxia town

From a comparative perspective, the evolution trend of pronunciation of the suffix “子” in Pinghua dialect used by Miao and Yao autonomous in southwest Hunan is clear, that is, affricate consonant firstly lost fricative property and weaken to the plosive [t], then further weaken to the liquid [l], accompanied by the vowel weakening and centralization. There are six gradations, the $1^{\text {st }}$ gradation is medieval phonetic, which is the source of the pronunciation development. All the colloquial pronunciations in southwest Hunan Pinghua dialect are reflected in the middle four gradations, that is the $2^{\text {nd }}$ to $4^{\text {th }}$ gradations on the pronunciation development chain. The $5^{\text {th }}$ and $6^{\text {th }}$ gradations are the writer's reference about the future development trend of suffix “子”.

According to the pronunciations of noun suffix “子” in other Chinese dialects, the further evolution trend can be predicted to be [•lə], such as in Ningyuan Pinghua dialect, then to be [•lə], such as in Yuanping dialect in Shanxi province (Local Chronicles Compilation Committee of Yuanping County, 1963) suffix “子” reads [•ə] generally, which completely lost consonant and centralized vowel. Finally, the result of evolution should be the 
vowel change equivalent to suffix “子” which is already exists in some Chinese dialects.

\section{Conclusion}

Taken together, there are many pronunciation forms of noun suffix “子” in Pinghua dialect used by Miao and Yao autonomous in southwest Hunan, literary pronunciation arising for the effect of Mandarin, while other colloquial pronunciations are the local unique pronunciation, which all come from the consonant weakening and vowel centralization, and maybe further evolve to be vowel change equivalent to suffix “子”. About pronunciation evolution of Chinese suffix “子”, in order to be more comprehensive and thorough, further study needs to develop analysis on typology combined with pronunciation forms of other dialects.

\section{Acknowledgements}

Sincere appreciation must be given to all persons who have given their support to the research. This paper is the research result of Research on Endangered Characteristics and Language Contact of Donghua Used by $\mathrm{Yao} \mathrm{Au}-$ tonomous in Xinning County which belongs to the "Philosophy and Social Science Fund Project of Hunan Province" (Project No. 2010 YBB351) and the "Youth Fund Project of Central South University of Forestry and Technology” (Project No. 2011QJ002).

\section{References}

Cui, S.S. (2013). The Comparative Study of Zi (子) at the End of Words in Anyang Dialect. Journal of Mudanjiang College of Education, 4, 34-35

Dai, G.Y. (2010). A study of Affix Zi in Xingtai Dialect. Thesis, Changsha: Hunan Normal University.

Hu, P. (2009). A Community of Pinghua Not to Be Neglected: A Comparative Study of the Sounds of the Pinghua Used by the Miao Nationality in the Southwest of Hunan Province. Journal of Hunan University of Science and Engineering, 3, 193-195

Local Chronicles Compilation Committee of Hebei Province. (2005). Local Chronicles of Hebei Province Dialect. Shijiangzhuang: Fangzhi Press.

Local Chronicles Compilation Committee of Yuanping County. (1963). Local Chronicles of Yuanping County. Beijing: China Science and Technology Press.

Luo, X.R. (2006). Research on the Vocabulary of Dialect in Southern Hunan. Changsha: Hunan Normal University Press.

Wang, L. (1985). The History of Chinese Phonetics. Beijing: China Social Science Press.

Wang, S.Y. (2007). Research on Xianzijiao Dialect in Dao County. Thesis, Changsha: Hunan Normal University.

Wu, J. (2010). Two Pronunciations of Suffix of Jintan Dialect in Jiangsu Province. Modern Chinese (Language Research), 1, 108-109

Zhang, S.F. (2008). The Phonetic Form of the Suffix Zi (子) and Correlative Issues in Shangqiu Dialect. Linguistic Science, 5, 518-525

Zhang, X.Q. (1999). Research on Ningyuan Pinghua Dialect. Changsha: Hunan Education Publishing House.

Zhao, X.Q. (2009). Research on Quantifiers of Shijiazhuang Urban Dialect. Thesis, Shijiazhuang: Normal University. 